\title{
INTELLIGENT TUTORING SYSTEM FOR REAL ESTATE MANAGEMENT
}

\author{
Artūras KAKLAUSKAS, Ruslanas DITKEVIČIUS \\ and Leonarda GARGASAITE் \\ Department of Construction Economics and Property Management, \\ Vilnius Gediminas Technical University, Sauletekio al. 11, LT-10223 Vilnius, Lithuania \\ E-mail: Arturas.Kaklauskas@st.vtu.lt, Leonarda@st.vtu.lt
}

Received 10 November 2005; accepted 23 March 2006

\begin{abstract}
The review on the worldwide intelligent tutoring systems and their application possibilities is presented in the paper. The intelligent tutoring system for real estate management developed by the authors is described. This system is applied in Vilnius Gediminas Technical University, Department of Construction Economics and Property Management. Besides the common components - student model, domain model, pedagogical model and graphical interface, the new developed system has testing model, decision support subsystem and database of computer learning systems. Domain model includes knowledge with the supplemental audio and video material for 63 modules being taught in Vilnius Gediminas Technical University. Student model enables to adapt to a learner needs and knowledge level. Decision support subsystem is used for all components of intelligent tutoring system giving them different level of intelligence. Database of computer learning systems enables using the following web-based learning systems: construction, real estate, facilities management, international trade, ethics, innovation, sustainable development, building refurbishment, etc. Tutor and testing model provide a model of the teaching process and support transition to a new knowledge state. Graphic interface is used to create an effective system-user dialogue.
\end{abstract}

KEYWORDS: Intelligent tutoring system; Life long learning; Real estate education

\section{INTRODUCTION}

The once acquired education does not assure successful career for the whole life in the rapidly changing today's market, globalisation and information world. Professionals in the real estate field must learn all life long. Distance learning proves to be very suitable, enabling graduates to study at their working place, home or just any time and place convenient for them. Getting more and more popular distance learning provides not only plenty of advantages, but also the challenges. In order to create necessary conditions for individualised learning, to increase quality and effectiveness of distance learning, the intelligent tutoring systems are applied.

The notion of intelligent machines for teaching purposes can be traced back to 1926 when Pressey built a machine with multiple choice questions and answers [15]. Intelligent tutoring systems (ITS) are an outgrowth of the earlier computer-aided instruction, which usually refers to a frame-based system with hard-coded links, i.e. hypertext with an instructional purpose [8]. However the start of artificial intelligence in education history is said to be 19501960. The scientists of this decade believed that the computers soon will think the same way as humans: Turing: Computing Machinery and

International Journal of Strategic Property Management

ISSN 1648-715X print / ISSN 1648-9179 online (C) 2006 Vilnius Gediminas Technical University

http://www.ijspm.vgtu.lt 
Intelligence [22], Minsky: Neural networks, Symbolic systems and mind society; McCarthy: Logical artificial intellect [18]). Programming works led to computerised teaching systems, that developed task sets, designed to support student learning [24, 25]. In the 1960's, researchers created a number of Computer Assisted Instructional systems that were generative [23]. By the late 1960's and early 1970's, many researchers had moved beyond merely presenting problems to learners while collecting and tabulating their responses, to considering the student a factor in the overall instructional system [24]. In 1970 the computer assisted instructional systems were improved by student models, enabling system to predict student answers. However in the seventies and early eighties the limitation of computerised systems was realised and investigation in artificial intelligence education decreased. The computerised tutoring systems were analysed mostly by educational and psychology experts. In 1982 a book „Intelligent tutoring systems” was published by Sleeman and Brown, where the modern computer assisted instructional systems were reviewed and the term Intelligent Tutoring System was introduced for the first time. It was defined as the system, that monitors, instructs and tutors students. Improving the intelligent tutoring systems further on, the computerised knowledge assessment function was proposed, as the mean for more effective learning [10]. In the early nineties when internet was started to be applied widely for transfer of information, the properties and actions of users were fixed and the information used to improve adaptive functions [3]. In the beginning of the 1990's, early ITSs focused their efforts on lesson navigation, or a kind of electronic page-turner presenting frames of text or graphics. This type of ITS is often referred to as a first generation ITS. Second generation ITSs use the model-tracing algorithm [1] to create a model of the student and trace student thinking [19]. ITSs where a model of both the student and the tutor are created in an effort to improve performance were the natural extension to second generation systems. Different researchers [9, 11] have developed third generation ITSs that model the tutor as well as the student.

At first intelligent tutoring systems were mostly applied in the courses of mathematics, later on they were adapted for more complicated topics and subjects. Recently the systems are designed also for history, philology or social sciences [9]. However the authors were not able to find any information about application of intelligent tutoring systems in the field of real estate. It seems that distance learning of real estate management is still performed in an old way, without benefits of new technologies.

When analysing the essence of intelligent tutoring systems (ITS), it is worth-while to take into account the research of other authors and institutions [4, 6, 7, 8, 20, 21, 26, 27]. One reason that ITSs are such a large and varied field is that "intelligent tutoring system" is a broad term, encompassing any computer programme that contains some intelligence and can be used in learning [8]. Therefore, in order to increase the degree of objectivity, we shall rely on the research of specialists and institutions working in this field. There are various intelligent tutoring system definitions such as:

$\checkmark$ A learning technology that dynamically adapts learning content to objectives, needs, and preferences of a learner by making use of his expertise in instructional methods and the subject to be taught [27].

$\checkmark$ The system that is using more articulate representations of the domain knowledge, so that the computer can reason about the knowledge it incorporates, besides merely presenting it, encoding didactical knowledge, so that the computer can reason about how it should communicate the appropriate information, including capabilities to model learner behaviour, for the purpose of monitoring, diagnosing, and curriculum planning, and providing an 
adaptive interface, which may include capabilities for language processing or graphical communication is called an intelligent tutoring system $[21,26]$.

$\checkmark$ A tutoring system is software whose aim is to communicate the knowledge of a domain (mathematics, language, etc.) to its user. Such a system is named "intelligent" mainly if it can adapt the interactions to the learner. Therefore, a tutoring system must have, among other things, some information about the user [7].

$\checkmark$ Intelligent Tutoring Systems (ITS) are software programs which provide instruction for a learner with guidance and insight in the way a teacher would guide a student. In an ITS program the knowledge of "how to teach" is distinct from that which is to be taught and from that which the student knows. Each of these areas of knowledge may be captured in a knowledge base or at least some form of an abstraction which the program operates upon to control its execution [14].

$\checkmark$ Broadly defined, an intelligent tutoring system is educational software containing an artificial intelligence component. The software tracks students' work, tailoring feedback and hints along the way. By collecting information on a particular student's performance, the software can make inferences about strengths and weaknesses, and can suggest additional work.

According to Freedman [8], the traditional ITS model contains four components: the domain model, the student model, the teaching model, and a learning environment or user interface. Wenger [26] presents the following model of ITS: Domain Expertise, Student Models, Pedagogical Expertise and Interface. Beck et al. [2] have identified five major components of ITS: Student Model, Pedagogical Module, Domain Knowledge, Communications Module and Expert Model. Each ITS must have these three components: knowledge of the domain, knowledge of the learner, knowledge of teacher strategies [15].

However because of high development and maintenance costs, lack of components reuse and standards usually only some research idea is investigated and the rest of a system is left just as infrastructure of components for only supporting research. The authors of publication [5] have proposed a mathematical model facilitating integration of computing and domain areas. Huang et. al. [12] have proposed learning parameter improvement mechanisms that calculate the students' effective online learning time, extract the portion of a message in discussion section which is strongly related to the learning topics, and detect plagiarism in students' homework, respectively. The authors of publication [28] have created an intelligent tutoring system capable of carrying on a natural language dialogue with a student who is solving a problem. The study performed by the scientists of publication [13] proposes a conceptual map model, which provides learning suggestions by analyzing the subject materials and test results.

However scientists are analysing different aspects of intelligent tutoring systems, there are thousands of the systems created, but not so many used. The reason - no general tutoring systems on real estate management does not exist. The authors have developed the intelligent tutoring system, from the beginning to the end, having all the interrelated components. The system is designed for tutoring real estate management.

This paper is structured as follows. Following this introduction, Sections 2-9 describe the Intelligent Life Long Learning Tutoring System for Real Estate Management: Structure (Section 2), Domain Model (Section 3), Student Model (Section 4), Decision Support Sub-system (Section 5), Database of Computer Learning Systems (Section 6), Tutor and Testing Model (Section 7) and Graphic interface (Section 8). Finally, some concluding remarks are provided in Section 9. 


\section{STRUCTURE OF THE INTELLIGENT LIFE LONG LEARNING TUTORING SYSTEM FOR REAL ESTATE MANAGEMENT}

The Intelligent Life Long Learning Tutoring System for Real Estate Management (ILLLTS-REM) has been created by authors in order to help employees to improve their qualifications in the field of real estate throughout their active professional life. This system enables learners to navigate in the information and knowledge variety and dynamically adapts learning content to objectives, needs, and preferences of a student by making use of his/her available expertise.

The Intelligent Life Long Learning Tutoring System for Real Estate Management consists of six subsystems:

- Domain Model,

- Student Model,

- Tutor and Testing Model,

- Database of Computer Learning Systems,

- Decision Support Subsystem,

- Graphic Interface.
The interrelationships among the components of the system are shown in Figure 1.

The subsystems are briefly analysed below.

\section{DOMAIN MODEL}

Domain Model (Domain Knowledge) component contains information the tutor is teaching, and is the most important since without it, there would be nothing to teach the student [7].

Since 1999 the e-learning Master degree studies "Real Estate Management" have been introduced in Vilnius Gediminas Technical University (VGTU), Master degree studies "Construction Economics" from 2000, and Master degree studies "Internet Technologies and Real Estate Business" from 2003 as well (See http:/ /odl.vtu.lt/). There are currently 220 master students from all over Lithuania studying in these three e-learning master programs.

63 modules are studied within the above programmes. All 63 modules with their supplement audio and video material are available at the ILLLTS-REM Domain Model.

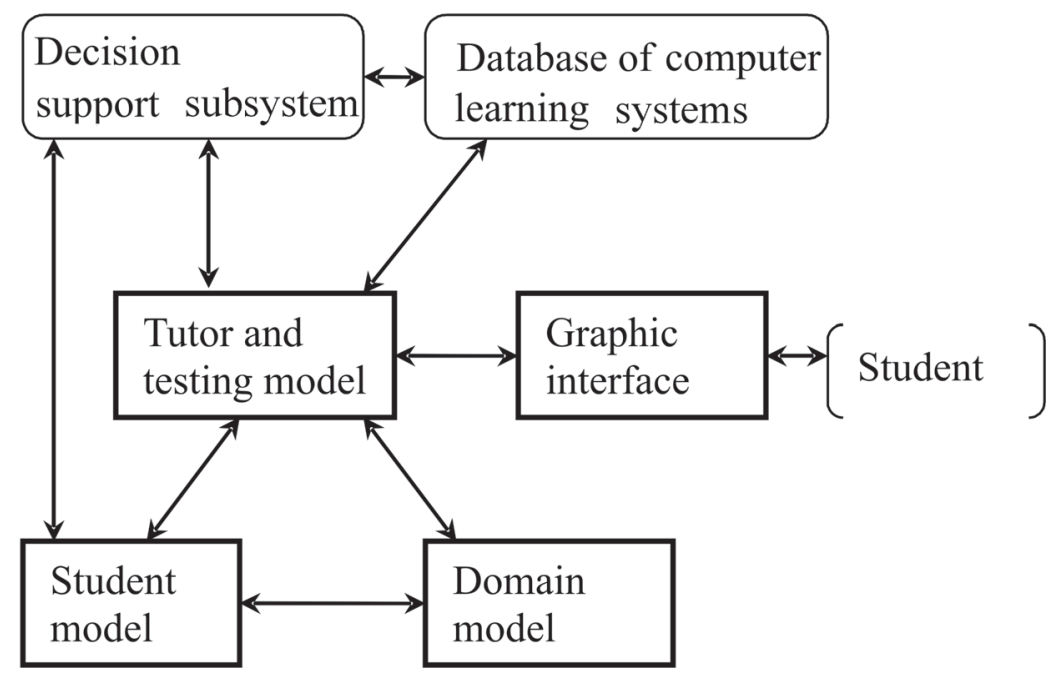

Figure 1. Structure of the Intelligent Life Long Learning Tutoring System for Real Estate Management 
Usually, the amount of the material for one subject in text form varies from 100 to 500 pages.

Different Web-based links are in the presented teaching material. These links provide better conditions for lesson navigation and acquiring more related information and knowledge.

After registration, students mark the sections of 63 modules they want to study in the electronic questionnaires. If a student has already participated in these e-learning studies, then the modules he/she has studied before are considered. The system can also offer study materials to students according to the repetitive key words in different modules. Mixed approach is also possible. The received information is used for the action plans: "mini curricula" that are used to lead the learner. Natu- rally, different students receive different study materials. For instance, if a student is working as a real estate broker, he/she receives study materials related to real estate buying, selling, broker activities, real estate contracts, etc.

A student may also find courses using the search page. He/she enters a phrase he is interested in and the system performs a search in course titles as well as in the learning material (Figure 2).

The courses may also be found in the catalogue that could be open by pressing "browse catalogue" (Figure 2 and 3 ).

Next to every course in the search page or catalogue, the link "Order" is provided. Clicking the link the course is included to the user basket (Figure 4).

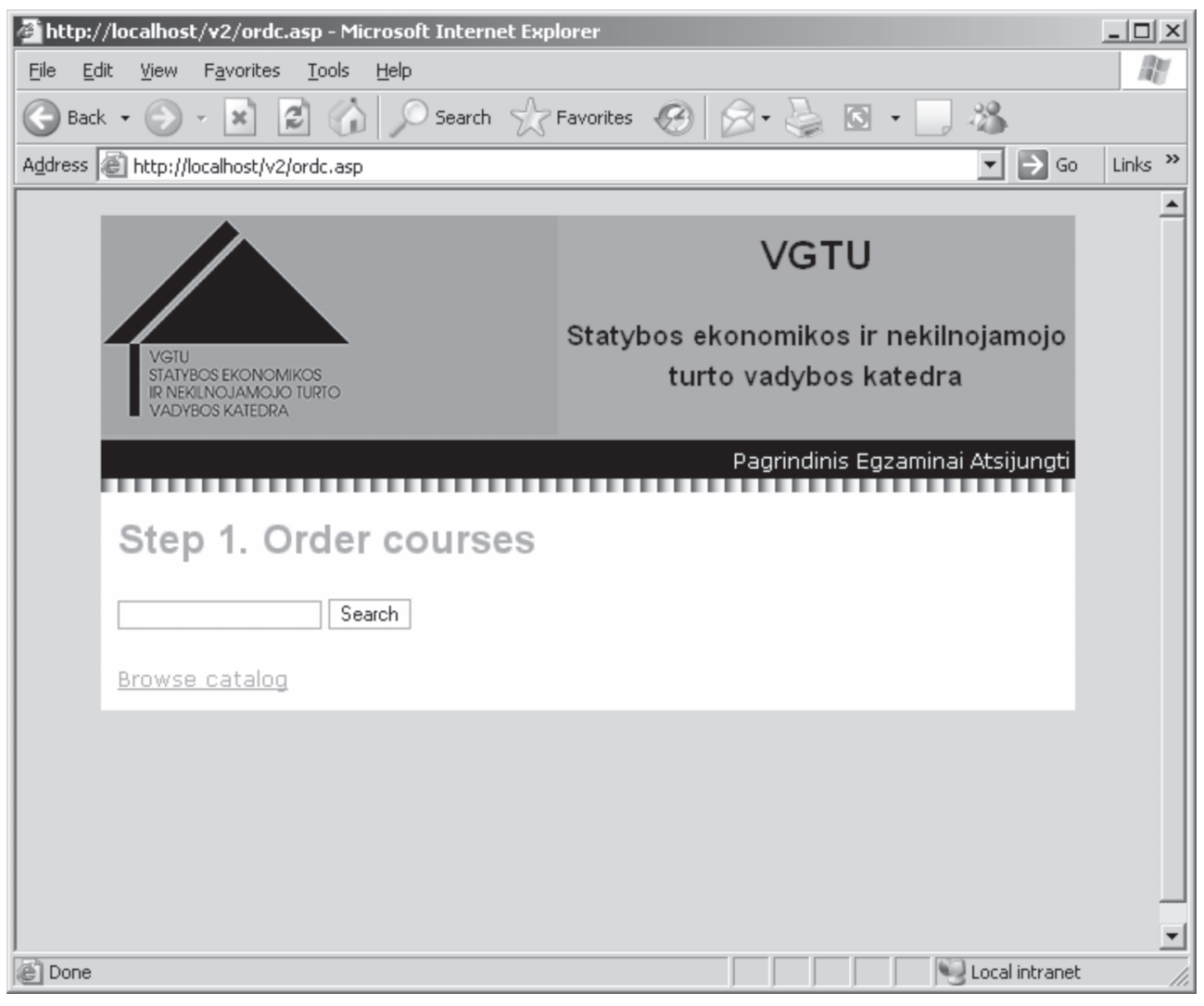

Figure 2. Course search page 


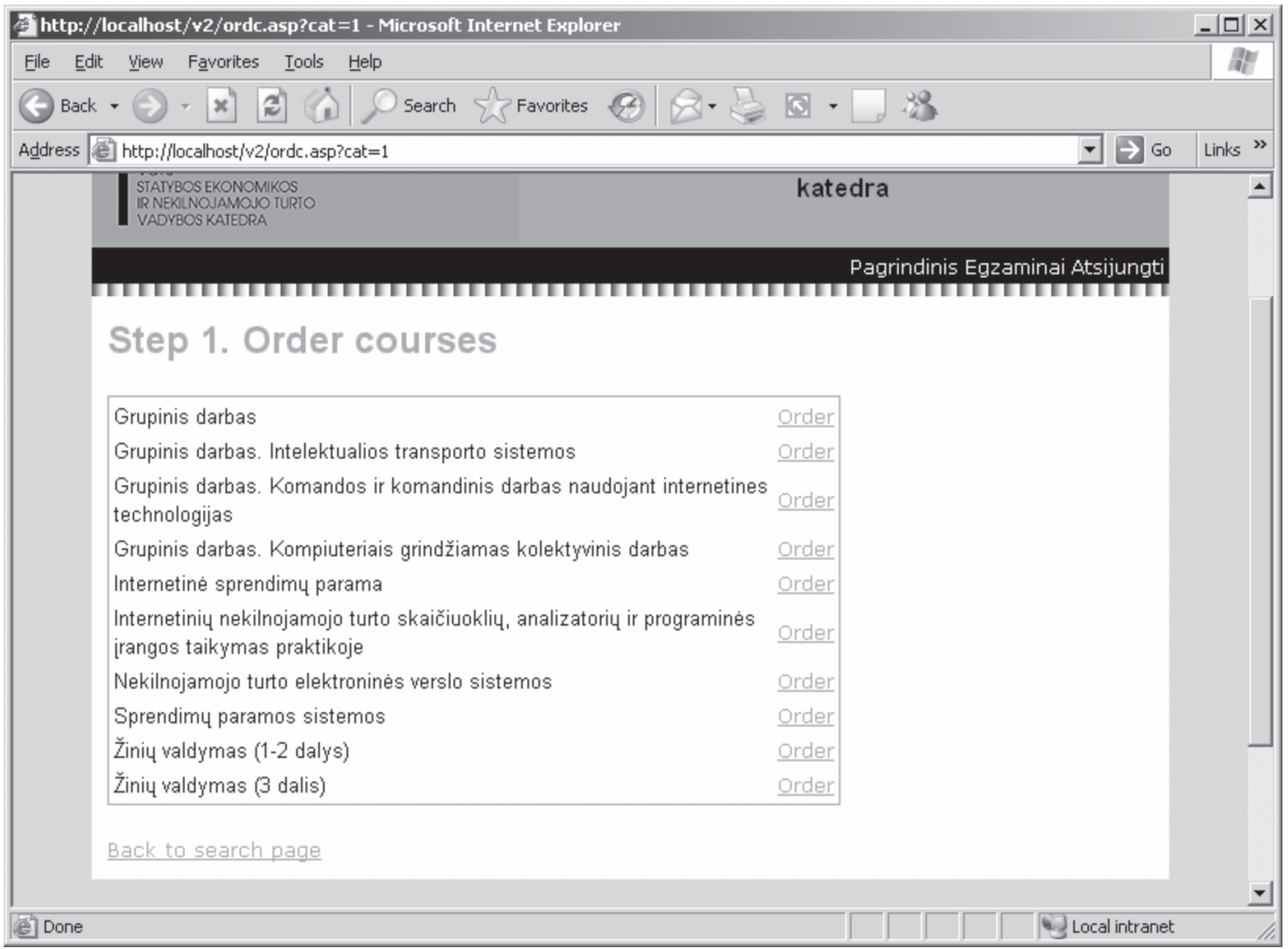

Figure 3. Course ordering catalogue

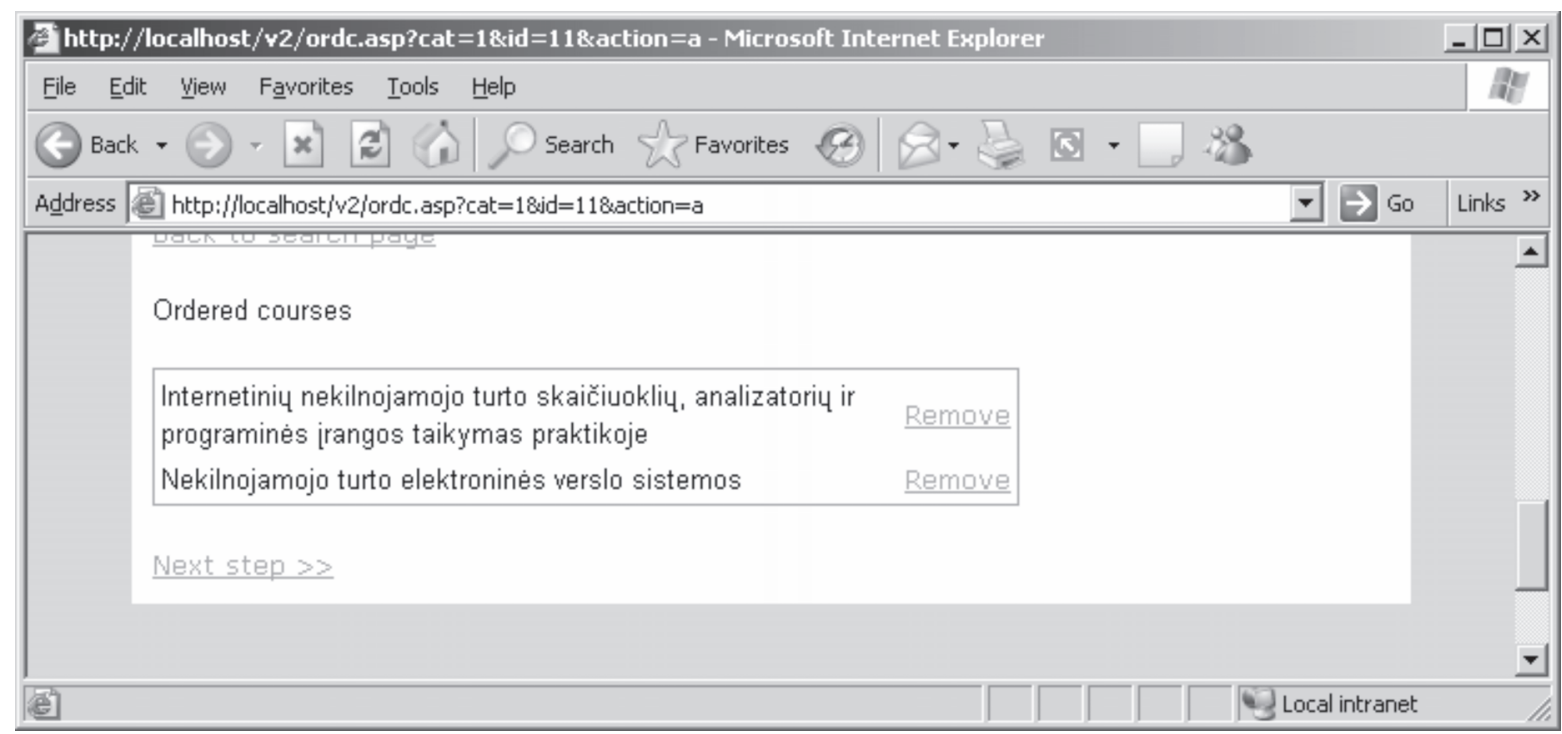

Figure 4. User basket 
If a student selects at least one course, a new link "Next step" appears, leading to the next ordering stage - submitting the user contacts (Figure 5).

Entered the requested contacts the user clicks "Finish" and the order is saved in a database. A student and the responsible university employee receive the notes about ordered courses by e-mail (Figure 6).

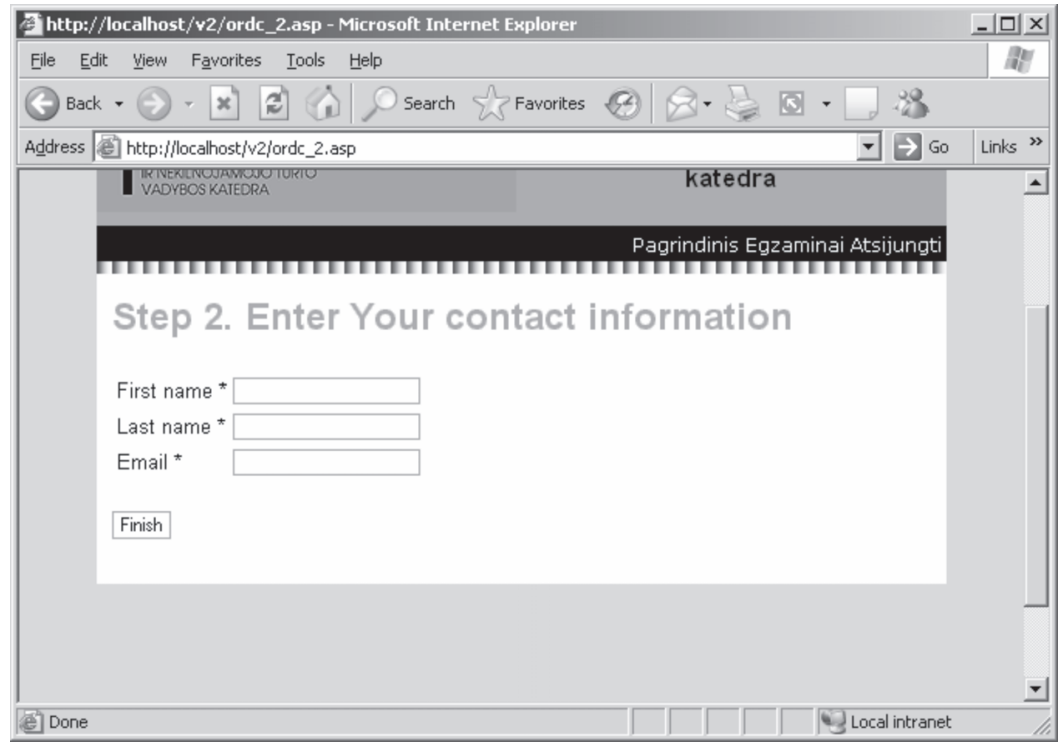

Figure 5. User contact submission

\begin{tabular}{|c|c|c|c|c|c|}
\hline \multicolumn{5}{|l|}{ A Notification } & $-\mid ㅁ ㅣ$ \\
\hline \multicolumn{5}{|c|}{ File Edit Yiew Iools Message Help } & \multirow[t]{2}{*}{ AP } \\
\hline \multicolumn{5}{|c|}{\begin{tabular}{|ccc|cc}
8 & 8 & 8 & $\underbrace{}_{\text {Rrint }}$ & $\underset{\text { Delete }}{\mathrm{C}}$ \\
\end{tabular}} & \\
\hline \multicolumn{6}{|c|}{$\begin{array}{ll}\text { From: } & \text { dikkevicius@odl.vtu.lt } \\
\text { Date: } & 2006 \mathrm{~m} \text {. balandžio } 7 \text { d. 09:49 } \\
\text { To: } & \text { ditkevicius@odl.vtu.lt; ditkevicius@odl.vtu.lt } \\
\text { Subject: } & \text { Notification }\end{array}$} \\
\hline \multicolumn{6}{|c|}{ Order for courses was received with following information } \\
\hline \multicolumn{6}{|c|}{ 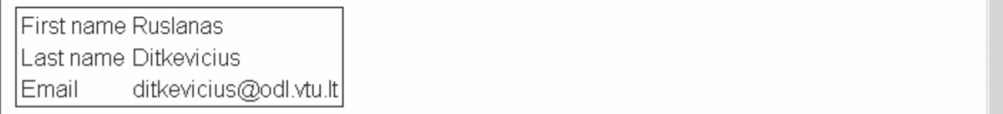 } \\
\hline \multicolumn{6}{|l|}{ Ordered courses: } \\
\hline \multicolumn{6}{|c|}{$\begin{array}{l}\text { ISP. } 3 \text { Internetiniu nekilnojamojo turto skaičiuokliu, analizatoriu ir programines irangos taikymas } \\
\text { ISP. } 2 \text { Nekilnojamojo turto elektroninès verslo sistemos }\end{array}$} \\
\hline \multicolumn{6}{|l|}{ Ref. No.: 33} \\
\hline \multicolumn{5}{|c|}{ Your order will be reviewed and response will be sent by email } & 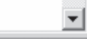 \\
\hline
\end{tabular}

Figure 6. Notification of the ordered courses 
The university employee reviews the orders. Clicking the link "Ref. No." he/she may revise the content of an order and decides which solution to take. He/she can reject an order, eliminate or change some courses or confirm the list of courses and proceed to the development of teaching plan. By clicking "Change" the coordinator may change the course list indicated the reasons of changes (Figure 7).

The revised course list is sent to a student by e-mail (Figure 8).

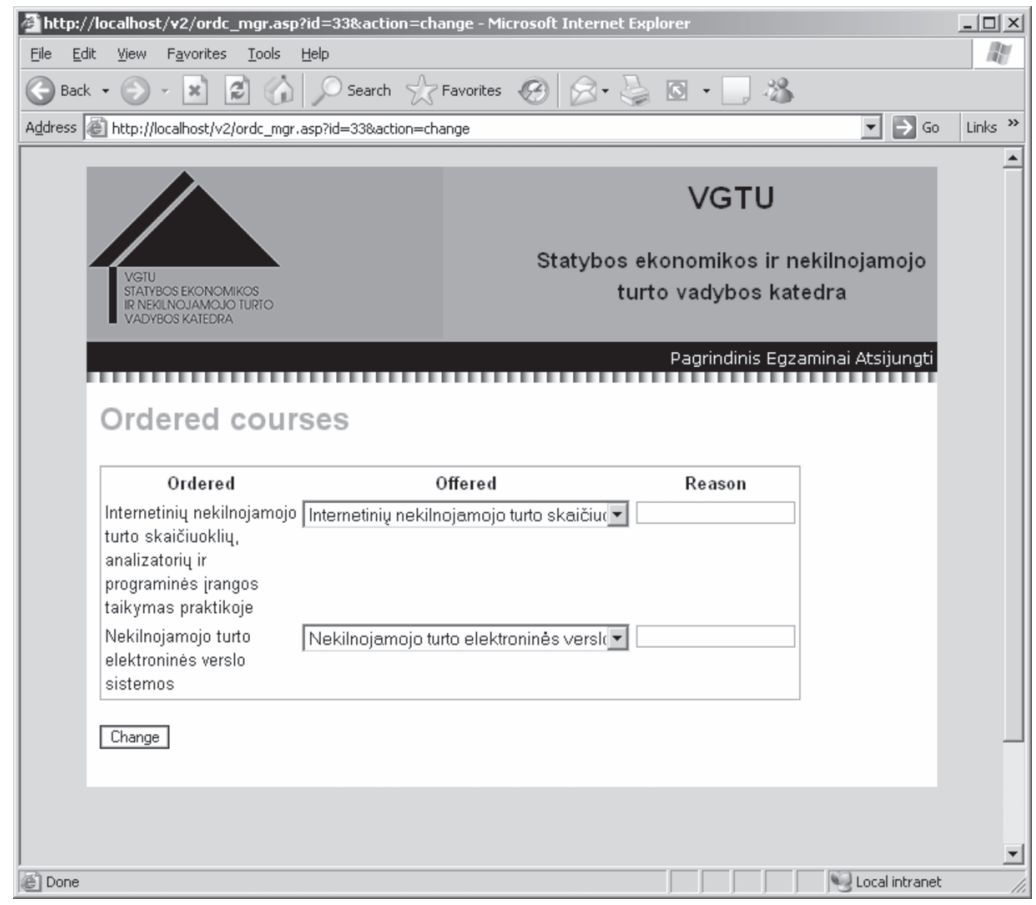

Figure 7. Changes in course list

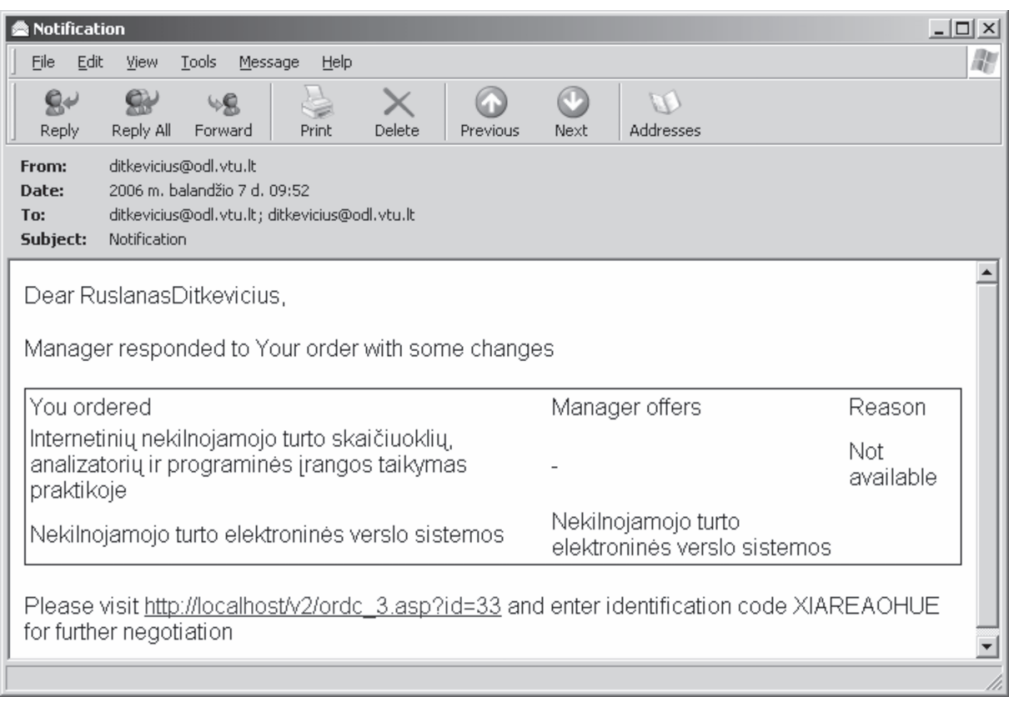

Figure 8. Course change information provided to a student 
Opening the indicated link and entering the identification code the student may confirm or reject the changes. After the list of courses is reconciled the coordinator creates a learning timetable offered to a student (Figure 9).
After developing the plan, coordinator may click "Reorder", then all the parts of a plan will be sorted in a chronological order. When the work is finish, a coordinator clicks "Send offer" and the learning plan is sent to a student by e-mail (Figure 10).

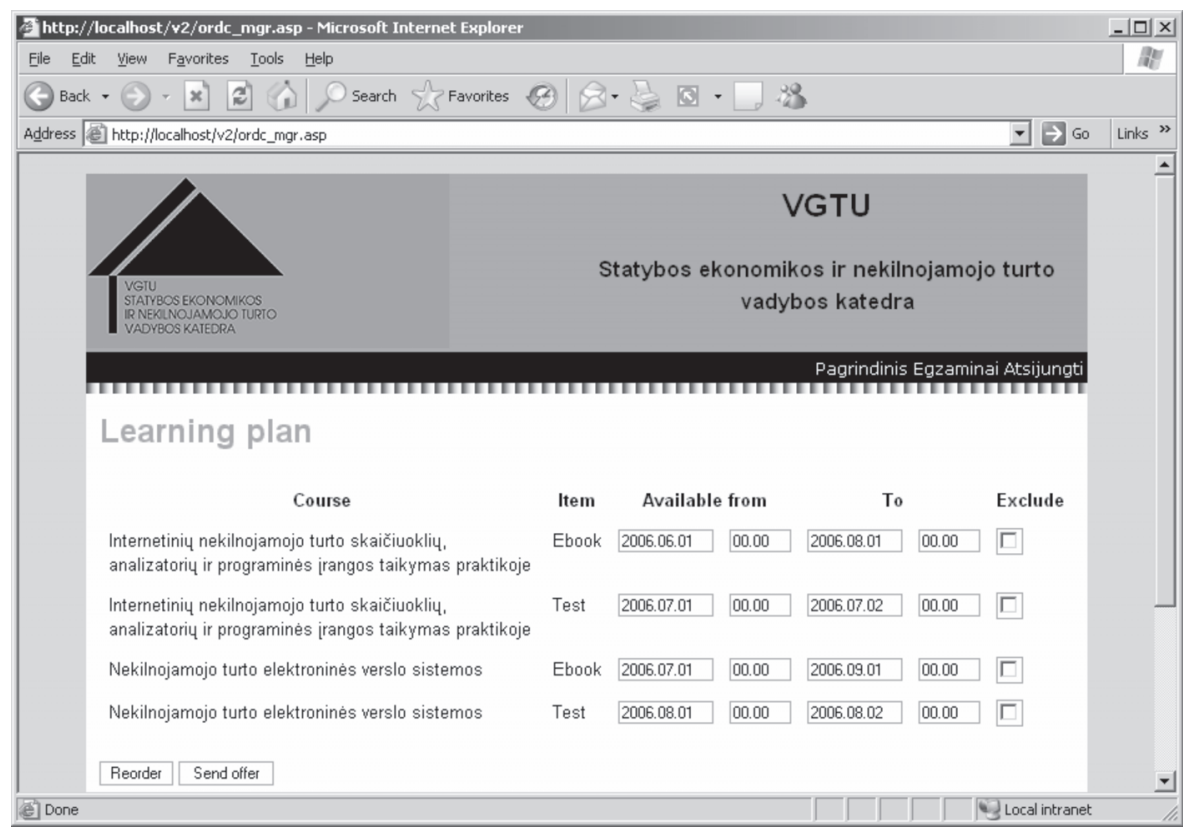

Figure 9. Timetable of courses

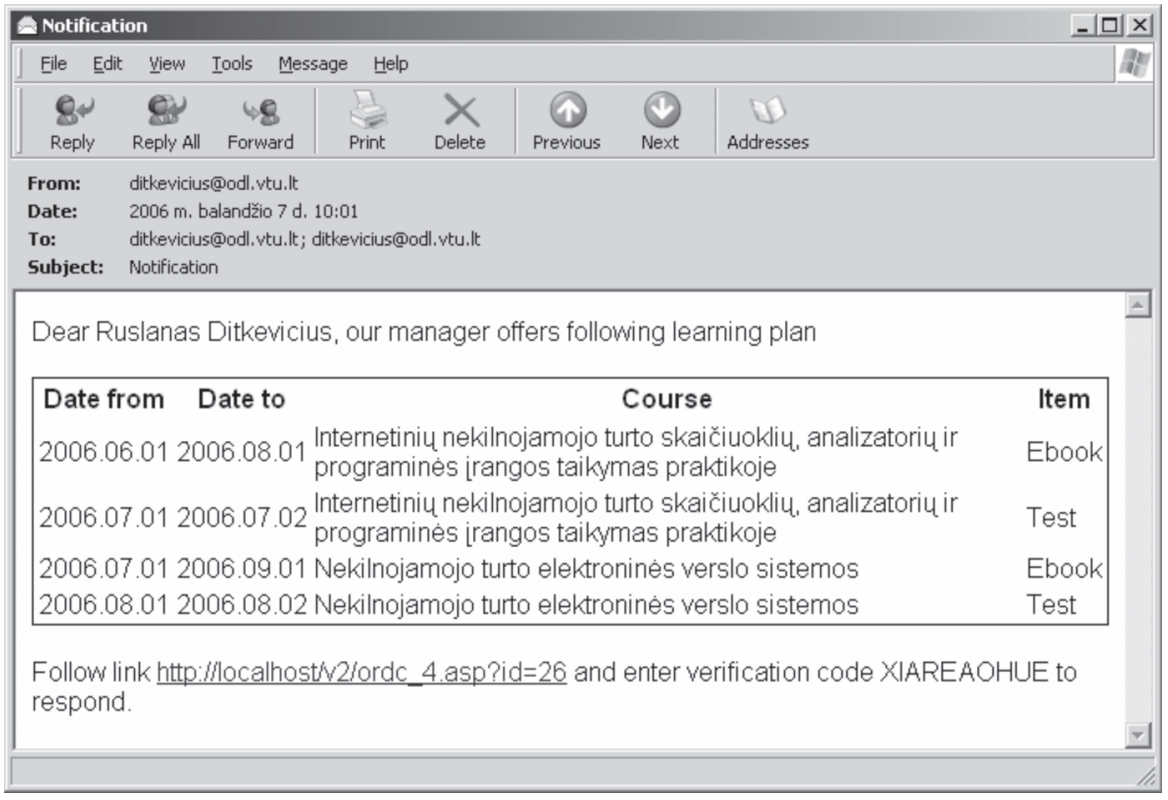

Figure 10. Learning plan offered to a student 
Now the procedure is exactly the same as the aforementioned. A student clicking the link and entering an identification code may revise the learning plan and decide to accept or to reject an offer.
After a student user confirms the learning plan, further instruction is provided (Figure $11)$.

The username and password are sent by email. Entering the sent data, a student may

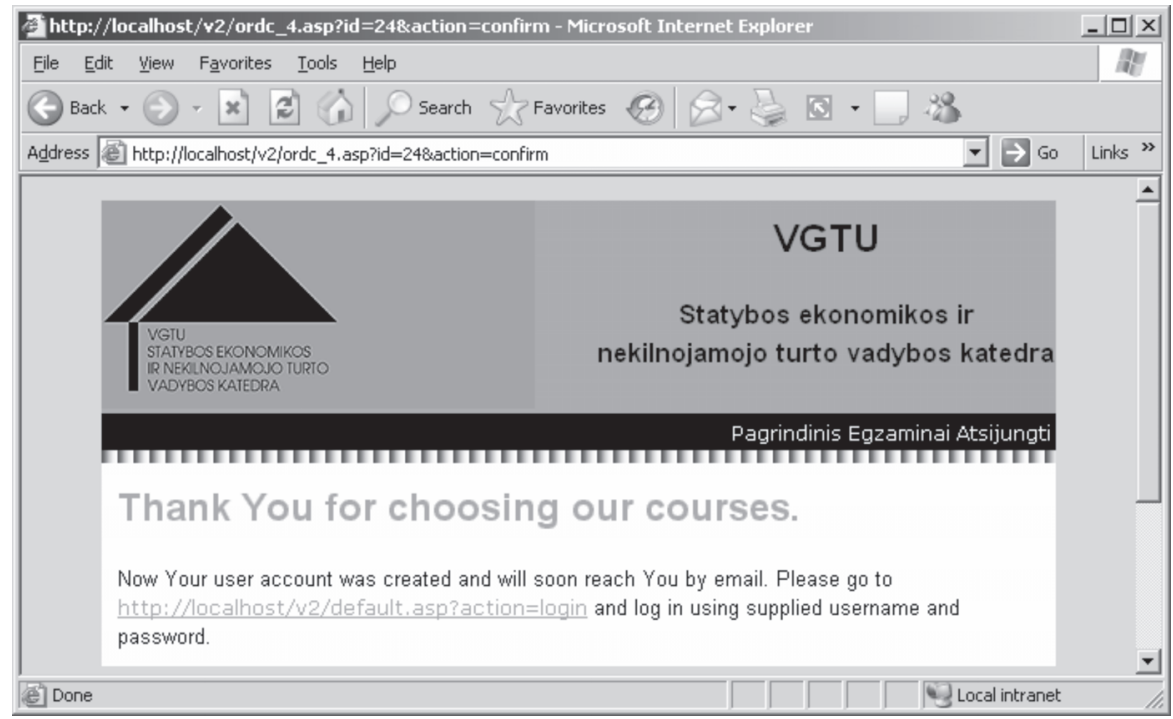

Figure 11. The last step of course ordering

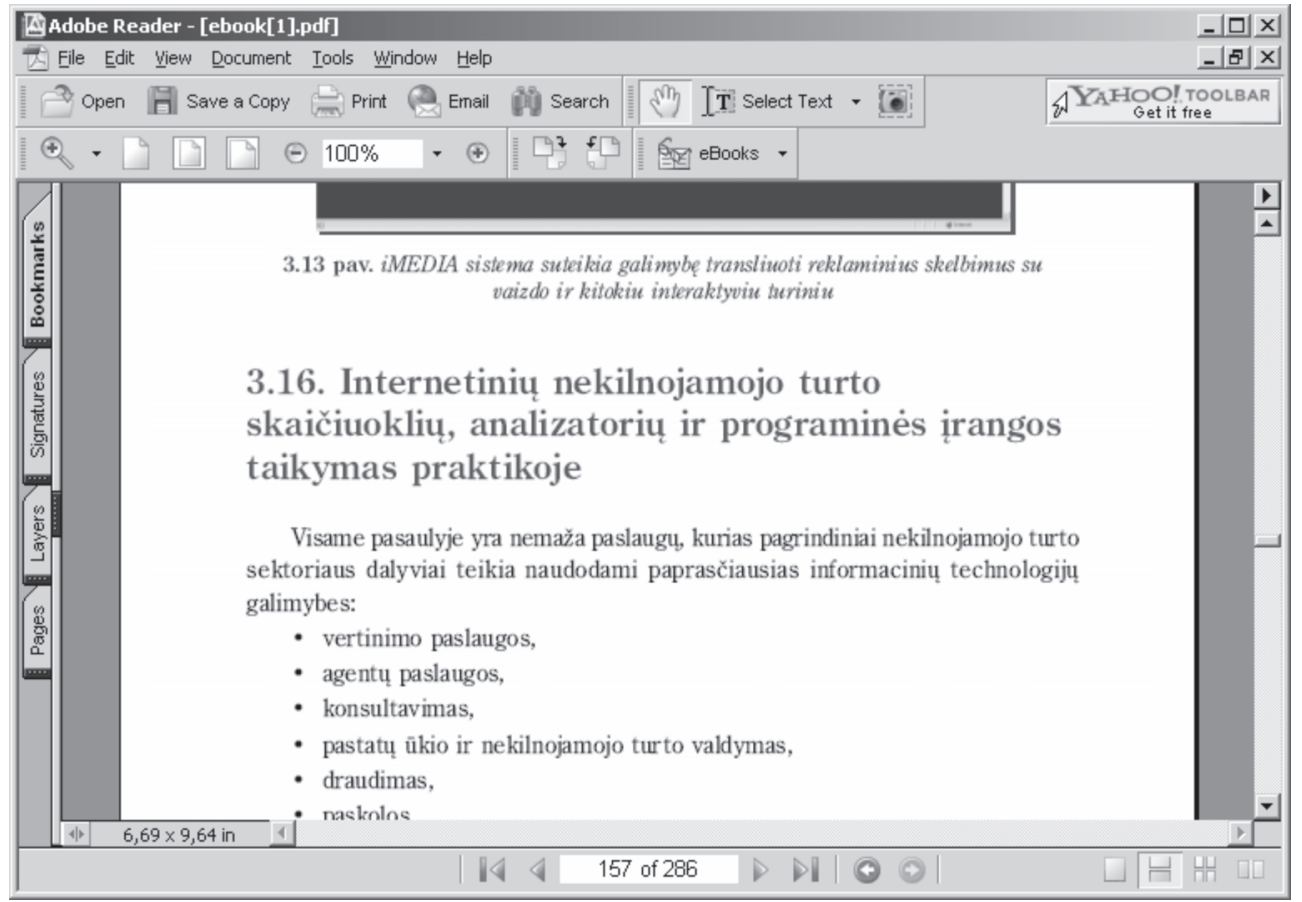

Figure 12. Fragment of an electronic book 


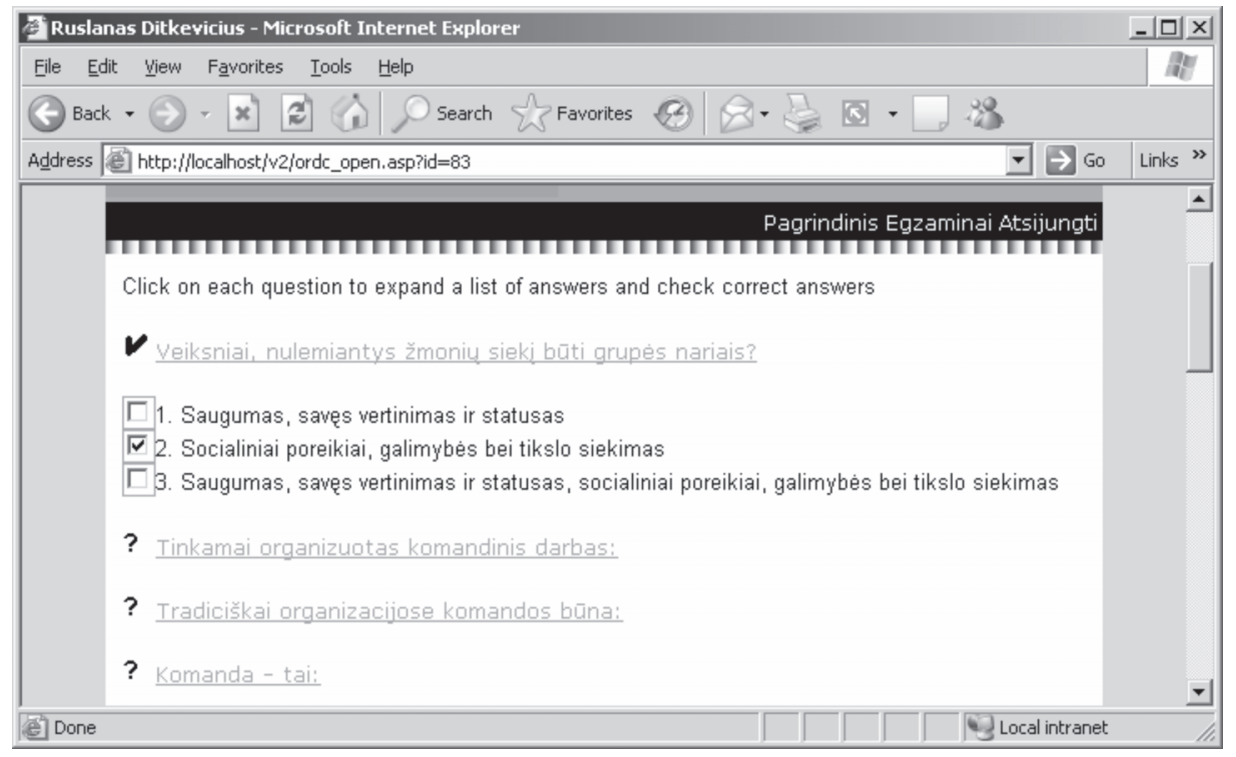

Figure 13. Fragment of a self-control test

connect to the system and automatically directed to his/her learning plan. The plan provides links to the available learning material. Selecting it a student may obtain the necessary parts of electronic books (Figure 12) and solve self-control tests (Figure 13).

\section{STUDENT MODEL}

ITS is named "intelligent" mainly if it can adapt the interactions to the learner. Therefore, a tutoring system must have, among other things, some information about the user [7].

The intelligent tutoring system starts by assessing the student knowledge of the subject or what the student already knows. Student Model uses that data to create a representation of the student's knowledge and learning process and represents the student's knowledge in terms of deviations from an expert's knowledge. On the basis of these deviations the system can decide what curriculum module, or chapter (subchapter) of module should be incorporate next, and how it should be pre- sented (text, multimedia, computer learning system, etc.).

The Student Model stores data that is specific to each individual student. This information can be explicit (year of born or university completion) or tacit. Explicit knowledge, i.e. information is widely used in information technologies. The main student knowledge is tacit. Tacit knowledge is comprised of informal and non-registered practice and skills. This knowledge is vitally important because it defines the abilities and experience of learners.

The Student Model is used to accumulate information about education of a student, his/ her study needs, training schedule, results of previous tests (if he/she has studied in the above-listed e-learning MSc programmes or qualification improvement courses before) and study results. Thus the Student Model accumulates information about the whole learning history of a student.

Since the purpose of the Student Model is to provide data for the Tutor Module, all of the data gathered should be able to be used by the Tutor module. 


\section{DECISION SUPPORT SUB-SYSTEM}

Decision Support Sub-system is used in mostly of all components of ILLLTS-REM (Domain Model, Student Model, Tutor and Testing Model, and Database of Computer Learning Systems) by giving different level of intelligence for these components.

Decision Support Sub-system aid in and strengthen some kind of decision process. Decision Support Sub-system is computer-based system that brings together information from a variety of sources, assist in the organization and analysis of information, and facilitate the evaluation of assumptions underlying the use of specific models. Decision Support Sub-system comprise of the following four constituent parts. These parts are: data (database and its management system), models (model base and its management system), user interface and message management system.

For example, ILLLTS-REM focusing on intelligence in the Integrated Web-based Negotiation Decision Support System for Real Estate (Database of Computer Learning Systems, See http://dss.vtu.lt/realestate/) can create value in the following important ways: search for real estate alternatives, find out alternatives and make an initial negotiation table, complete a multiple criteria analysis of alternatives, make negotiations based on real calculations, determine the most rational real estate purchase variant, and complete an analysis of the loan alternatives offered by certain banks. Figure 14 shows an example how the market value calculations are presented in a graphical form.

Also by using a Decision Support Sub-system, the tutor can compare the learner's solution to the expert's solution, pinpointing the places where the learner had difficulties. Decision Support Sub-system have been developed by using multiple criteria methods [17, 29 ] as was developed by the authors.

\section{DATABASE OF COMPUTER LEARNING SYSTEMS}

The database of computer learning systems enables using of the following Web-based computer learning systems:

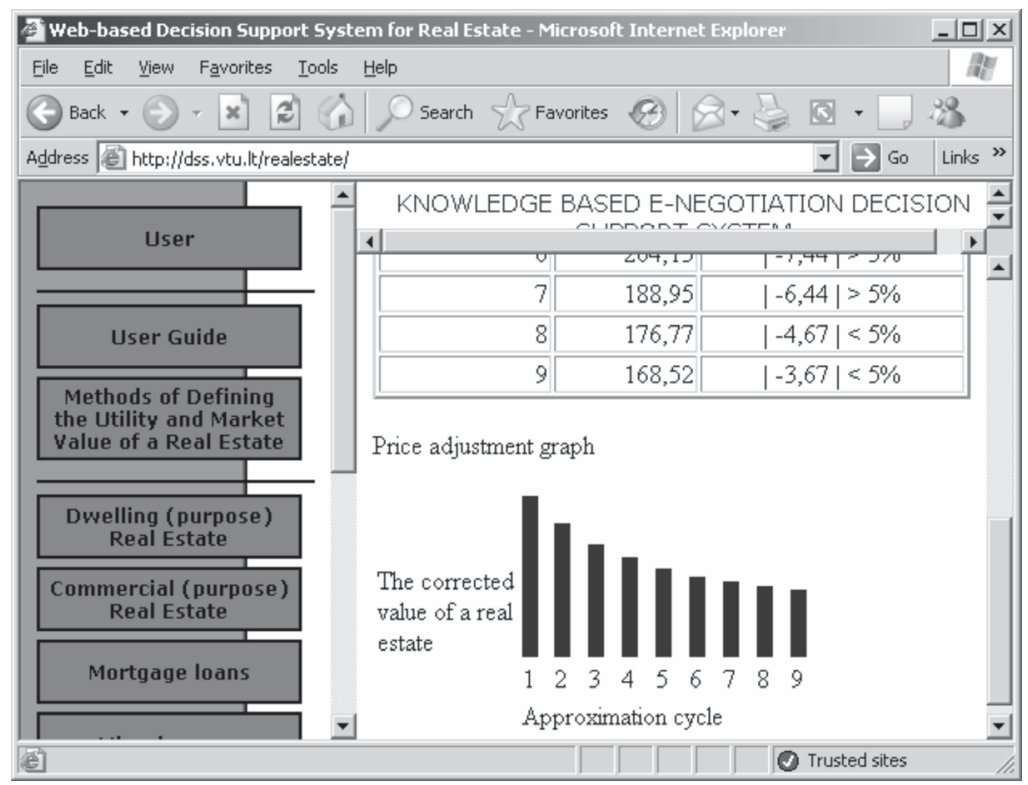

Figure 14. Presentation of the market value calculations in a graphical form 
$\checkmark \quad$ E-negotiation computer learning system for real estate (http://dss.vtu.lt/ realestate/).

$\checkmark$ Web-based innovation computer learning system (http://dss.vtu.lt/ default_eng.asp).

$\checkmark$ Web-based construction computer learning system (http://smg.vtu.lt/ statyba/index.php?kalba1=en).

$\checkmark$ Web-based computer learning system for public buildings renovation (http:/ / d s s.vtu.lt/renovacija/ index_educational.asp).

$\checkmark$ Web-based computer learning system for renovation of large panel buildings (http://dss.vtu.lt/renovacija/ index_eng.asp).

$\checkmark$ Web-based computer learning system for sustainable development (http:// dss.vtu.lt/default_eng.asp).

$\checkmark$ Web-based decision support system for facilities management (http://dss.vtu.lt/ default_eng.asp).

$\checkmark \quad$ Web-based computer learning system for loan analysis (http://dss.vtu.lt/ default_eng.asp).

$\checkmark$ Web-based computer learning system for ethics alternative analysis (http:// dss.vtu.lt/default_eng.asp).

The above mentioned systems have been developed by using multiple criteria methods $[17,29]$ as was developed by the authors. Each computer learning system consists of a database, a database management system, modelbase, a model-base management system and a user interface.

Application of multiple criteria computer learning systems developed by authors allows one to determine the strengths and weaknesses of analysed alternatives and its constituent parts. Calculations were made to find out by what degree one version is better than the other and the reasons disclosed why it is namely so. Landmarks are set for an increase in the efficiency of versions. All this was done argumentatively, basing oneself on indexes under investigation, on their values and weights. This saved students' time considerably by allowing them to increase both the efficiency and quality of e-learning. Below is a list of typical problems solved by graduates in their course and diploma projects:

- Multiple criteria analysis and determination of market value of a real estate (e.g. residential houses, commercial, office, warehousing, manufacturing and agricultural buildings, etc.).

- Analysis and selection of a rational real estate version.

- Multiple criteria analysis and determination of the highest and best use of a real estate.

- Determination of efficient investment instruments.

- Determination of efficient investment projects.

- Determination of efficient financing instruments.

- Multiple criteria analysis of a property's obsolescence.

- Alternative design of a project's lifetime process (i.e. one-family dwelling houses, agricultural buildings, cast-inplace buildings, prefabricated panel buildings, refurbishment of buildings, etc.), its multiple criteria evaluation, determination of utility degree and the selection of the most efficient version.

The use of multiple criteria computer learning systems in solving various problems encountered in the course and diploma projects was also aimed at determining: student's knowledge acquired at the university, student's general level of education, student's keenness of mind, student's ability of fast and adequate response to changing situation.

\section{TUTOR AND TESTING MODEL}

The Domain Model presents frames to the learner. Tutor and Testing Model provide a model of the teaching process and support the transition to a new knowledge state. For example, information about when to test, when 
to present a new topic, and which topic to present is controlled by this module. The Tutor and Testing Model reflect teaching experience of associate professors or professors. The Student Model is used as input to this component, so the Tutor and Testing Model decisions reflect the differing needs of each student.

The Tutor and Testing Model formulates questions of various difficulties, specifies sources for additional studies and helps to select literature and multimedia for further studies and a computer learning system to be use during studies.

Student can select the level of difficulty at which the teaching takes place. For example, the chapters of modules with mathematical orientation (i.e. mathematical methods used for estimation for market or investment value) are quite difficult for some students.

Traditional testing systems evaluate learner's state by giving them a mark and do not provide a possibility to learn about own knowledge gaps or to improve knowledge in any other way. The Tutor and Testing Model compare the knowledge possessed by a student (test before studies) and obtained by a student during studies (test after studies) and then it performs a diagnosis based on the differences. By collecting information on a history of a student's responses, the Tutor and Testing Model provide feedback and help to determine strengths and weaknesses of student's knowledge, new knowledge obtained during studies is summarized and various recommendations and offers are provided. After giving feedback, the system reassesses and updates the student skills model and the entire cycle is repeated. As the system is assessing what the student knows, it is also considering what the student needs to know, which part of the curriculum is to be taught next.

Also there is an option of selection of the following question in a test depending on the correctness of answers to the previous questions. Correct answers lead to the more difficult, incorrect - to the easier ones.

The obtained knowledge is the difference between the possessed knowledge (test before studies) and the final knowledge (test after studies). The Tutor and Testing Model also explain why one or another answer is correct/ incorrect and offers certain additional literature and multimedia related to the incorrectly answered question.

Applying ILLLTS-REM, a tutor does not renew tests for every learner. Questions are saved in a question database and hundreds of test alternatives are developed casually.

The questions base of the Tutor and Testing Model accumulates the following information:

- Questions according to modules,

- Possible answers to the question,

- Evaluation of correctness of possible answer versions. An incorrect answer is evaluated by zero and a correct is evaluated by one; intermediate answers get from 0 to 1 ,

- Difficulty of a question determined on the basis of the results of previous tests taken by other students,

- Link to the study material related to the question,

- Time allocated for testing.

Having such a question data base, it is possible to create tests also in a non random way, but to individualize it for each student according to the number of questions, their difficulty and proportion of questions of different topics. Received test results are saved in the results data base.

Using statistics provided by the Tutor and Testing Model, students can see the question difficulty, average evaluation of the whole group and learn about their position in the group before and after studies. Saving the data on question difficulty, the opportunity of giving the easier questions first of all later moving on to the more complicated ones occurs. Similarly the topics can be selected - from the simpler to the more difficult repeating the most complicated topics.

Thus on the basis of the compiled questions base, questions for tests are formulated not randomly; they are individually adjusted to 
each student according to the number of questions, their complexity and the proportion of questions from different modules. It is also possible to give easier questions in the beginning and then to proceed to more complex. Similarly, it is possible to select the taught subject from easier to more complex and to repeat subjects that are not mastered yet.

If a student has already participated in these studies, then the complexity of his/her test is determined by the Tutor and Testing Model on the basis of his/her average evaluation and interests. Thus after registration the system gives the student questions considering the average evaluation of his/her previous studies and his/ her interests (job of the student, cognition interests, etc.). Those who take qualification improvement courses for the first time are given average complexity questions by the Tutor and Testing Model. Therefore, students are passing tests of various complexities.

Student can select the level of difficulty at which the testing takes place. For example, the testing questions with mathematical orientation (i.e. mathematical formulas used for decisionmaking) are not desirable for some learners.

A student takes a test on the Web site. The Tutor and Testing Model automatically evaluates the answers, analyses them and sends the analysis results to the student, including correct and incorrect answers, grades and explanations on where to find more information about the question under consideration as well as explanations of the answers. One of the advantages is that information is provided to the student straight after he/she completes the self-control test. Therefore the system is valuable not only as an assessment tool, but also as learning mean.

A lecturer applying the system enters his/ her user name and password on the internet site. Questions can be generated by the system itself or can be selected by a lecturer. The system provides information on testing process in a matrix and graphical form:

- Information on correct and incorrect answer,
- Time distribution to every question,

- Number of times a student has changed an answer to each question of a test.

In the columns of the tables the number of a student is indicated, in the rows - the number of a question. The correct answers are marked from 0 to 1 (including 0,5 and other intermediate values), 1 means that the answer is correct, 0 - incorrect. Similar tables are designed also for the time distribution (here the time for each answer is indicated in seconds) and for parameters of student doubts to select one or another answer (the number shows how many times the answer was changed to another one).

Also the complex parameters are presented, where not only the correctness of the answer is evaluated, but also the time required for student to answer as well as the doubts of selection. Evaluating the answer by a complex parameter, the knowledge assessment may even change.

From the information provided the general view on strong and week points of the module and its test properties may be generated and the suggestions for improvement derived.

The presented information also helps to determine the more difficult and the easier question. The difficulty is determined by complex parameters, it is continuously adjusted until it becomes reasonable and stable. In this way the intelligent testing system helps a student not to get lost in the information overload, providing individualized learning guidelines, ignoring too simple course material therefore decreasing cognitive load and providing more complicated course material for further improvement therefore not frustrating the student motivation.

The developed intelligent testing system also provides a lecturer with a statistical analysis of students' answers according their gender and type of studies - full-time or distance. Also it can show the distribution of answering results by gender. 
The further trends of improving the system involve development of adaptive testing function in the testing system when the sufficient statistical data on question difficulty is available.

\section{GRAPHIC INTERFACE}

A modern intelligent tutoring system can implement its functions effectively only when users can have active dialogue with a computer by using means for dialogue organisation determining how the information is provided and how the information and commands are interchanged. Therefore, the system-user dialogue is important, as well as the interface (dialogue system) helping to have comfortable and effective dialogue. Without a suitable interface user cannot have full advantage of the system features. The user interface includes all mechanisms for data input and for output of results from the system. Various user interface types are used (commands, menu, graphic, etc.). This system has graphic interface: icons in windows opened in the computer screen show data, models and other objects available in the system. By graphic interface a user can control data, knowledge and subsystems and to review the results in the computer screen or to have them printed.

\section{CONCLUSIONS}

Analysis of the worldwide intelligent tutoring systems has shown that there are no systems developed for the field of real estate management. Despite that, high development and maintenance costs, lack of components reuse and standards usually leads to investigation of just research idea while the rest of a system is left just as infrastructure of components for only supporting research. There is no general tutoring construction environment. The authors have developed the intelligent tutoring system, from the beginning to the end, having all the interrelated components and introducing some new. The system is designed for tutoring real estate management.

The Intelligent Life Long Learning Tutoring System for Real Estate Management developed by authors consists of six subsystems: Domain Model, Student Model, Tutor and Testing Model, Database of Computer Learning Systems, Decision Support Subsystem, Graphic Interface.

Domain model includes knowledge with the supplemental audio and video material for 63 modules being taught in Vilnius Gediminas Technical University. Student model enables to adapt to a learner needs and knowledge level. Decision support subsystem is used for all components of intelligent tutoring system giving them different level of intelligence. Database of computer learning systems enables using the following web-based learning systems: construction, real estate, facilities management, international trade, ethics, innovation, sustainable development, building refurbishment, etc. Tutor and testing model provide a model of the teaching process and support transition to a new knowledge state. The model allows assessment of knowledge not only by the correct/incorrect answer, but also takes into account the time taken for a student to answer a question and the doubts appeared, the complex parameters, etc. The developed system provides support to the student by presenting explanations of the answers and the links to certain literature. It provides statistical analysis on knowledge acquirement depending on the gender of the student and the type of studies the student is involved in - distance or full-time. For the teacher the system is also useful because it helps to evaluate the correctness of a question formulation, difficulty of a question and directions for refinement of a test or a model, etc. Graphic interface is used to create an effective system-user dialogue. 


\section{REFERENCES}

[1] J. R. Anderson, A. Corbett, K. Koedinger and R. Pelletier, Cognitive Tutors: Lessons Learned, Journal of the Learning Sciences, 4(2), 1995, p. 167-207.

[2] J. Beck, M. Stern and E. Haugsjaa, Applications of AI in Education. http://www.acm.org/ crossroads/xrds3-1/aied.html [accessed 200601 14]

[3] P. Brusilovsky, Methods and techniques of adaptive hypermedia, User Modelling and User Adapted Interaction, 6 (2-3), 1996, p. 87-129.

[4] J. R. Carbonell, Artificial intelligence approach to computer assisted instruction, $E$ - transactions on Man-Machine Systems, 11 (4), 1990, p. 190-202.

[5] S. G. Curilem, A. R. Barbosa and M. F. de Azevedo, Intelligent tutoring systems: Formalization as automata and interface design using neural networks, Computers \& Education, In Press, http://www.sciencedirect.com [accessed 200602 24]

[6] R. Freedman, S. S. Ali and S. McRoy, What is an Intelligent Tutoring System? ACM Intelligence, 2000 Fall, p. 15-16.

[7] D. Frédéric. Modélisation de l'apprenant dans un logiciel d'Enseignement Intelligemment Assisté par Ordinateur: Application à un tutoriel intelligent dédié aux composés anglais, http://www.inria.fr/rrrt/tu-0872.html [accessed 200601 18]

[8] R. Freedman, What is an Intelligent Tutoring System? http://www.cs.niu.edu/ freedman/papers/link2000.pdf [accessed 200511 10]

[9] C. Graesser, N. Person, D. Harter and the Tutoring Research Group, Teaching tactics and dialog in AutoTutor, International Journal of Artificial Intelligence in Education, 2001, 12, p. 257-279.

[10] N. Hammond and L. Allinson, Extending hypertext for learning: An investigation of access and guidance tools, People and Computers, 1989.

[11] N. T. Heffernan, Web-Based Evaluation Showing both Motivational and Cognitive Benefits of the Lindquist Tutor, SIGdial endorsed Workshop on "Empirical Methods for Tutorial Dialogue Systems" which was part of the International Conference on Intelligent Tutoring System 2002.
[12] C. J. Huang, S. S. Chu and C. T. Guan, Implementation and performance evaluation of parameter improvement mechanisms for intelligent e-learning systems, Computers \& Education, In Press, http://www.sciencedirect.com [accessed 200602 24]

[13] G. J. Hwang, A conceptual map model for developing intelligent tutoring systems, Computers \& Education, 40(3), 2003, p. 217-235.

[14] Innovative Projects Lab, What is an Intelligent Tutoring System? http://www.ipli.com/ topicfaq.htm [accessed 200602 24]

[15] Intelligent Tutoring Systems, http:// coe.sdsu.edu/eet/Articles/tutoringsystem/ start.htm [accessed 200602 24]

[16] Internet site of distance learning of VGTU Faculty of Civil Engineering, Department of Construction Economics and Property Management, containing tests: dss.vtu.lt/inttestai.

[17] A. Kaklauskas, E. K. Zavadskas and S. Raslanas, Multivariant Design and Multiple Criteria Analysis of Building Refurbishments, Energy and Buildings, 37(4), 2005, p. 361-372.

[18] J. McCarthy, Programs with Common Sense, Mechanisation of Thought Processes, Proceedings of the Symposium of the National Physics Laboratory, 1959, p. 77-84, London, U.K. Her Majesty's Stationery Office. Reprinted in 1990.

[19] S. Ohlsson, Some principles for intelligent tutoring, Instructional Science, 17, 1986, p. 281307.

[20] L. M. Razzaq, Tutorial Dialog in an Equation Solving Intelligent Tutoring System, A Thesis Submitted to the Faculty of the Worcester Polytechnic Institute, 2003.

[21] D. H. Sleeman, J. S. Brown, Intelligent Tutoring Systems, New York: Academic Press, 1982, p. 79-98.

[22] M. Turing, Computing machinery and intelligence. Mind, 59, 1950, p. 433-460. http:// www.loebner.net/Prizef/TuringArticle.html [accessed 200601 18]

[23] L. Uhr, Teaching machine programs that generate problems as a function of interaction with students, Proceedings of the 24th National Conference, 1969, p. 125-134.

[24] M. Urban-Lurain. Intelligent Tutoring Systems: An Historic Review in the Context of the Development of Artificial Intelligence and Educational Psychology. http://www.cse.msu.edu/rgroups/ cse101/ITS/its.htm [accessed 200601 18] 
[25] R. Venezky and L. Osin, The intelligent design of computer-assisted instruction, New York: Longman, 1991.

[26] E. Wenger, Artificial intelligence and tutoring systems: computational and cognitive approaches to the communications of knowledge, San Francisco: Morgan Kaufmann Publishers Inc., CA, 1987.

[27] www.erudium.polymtl.ca/html-eng/ glossaire.php [accessed 200601 18]

[28] W. Woo, M. W. Evens, R. Freedman, M. Glass, L. S. Shim, Y. Zhang, Y. Zhou and J. Michael, An intelligent tutoring system that generates a natural language dialogue using dynamic multi-level planning, Artificial Intelligence in Medicine , 36(1), 2006, p. 85-117.
[29] E. K. Zavadskas, A. Kaklauskas, A. Banaitis and N. Kvederytè, Housing Credit Access Model: the Case for Lithuania, European Journal of Operation Research, 155(2), 2004, p. 335352.

[30] E. Zavadskas, P. Vainiūnas, M. Gikys. Property management in postgraduate Internet studies in Vilnius Gediminas Technical University, In Z. J. Pudlowski and H. P. Jensen, eds., Proceedings of 4th Baltic region Seminar on Engineering Education, Lyngby, Copenhagen, Denmark, 2000, p. 83-86.

[31] E. K. Zavadskas, A. Kaklauskas, Efficiency increase in research and studies while applying up-to-date information technologies, Statyba (Civil Engineering), 6(6), 2000, p. 397-414.

\section{SANTRAUKA}

\section{INTELEKTUALI NEKILNOJAMOJO TURTO VADYBOS MOKYMO SISTEMA}

\section{Artūras KAKLAUSKAS, Ruslanas DITKEVIČIUS, Leonarda GARGASAITE்}

Straipsnyje pateikiama išsami intelektinių mokymo sistemų bei jų taikymo galimybių analizè. Aprašoma nekilnojamojo turto vadybos intelektine mokymo sistema, sukurta autorių. Ji taikoma Vilniaus Gedimino technikos universiteto Statybos ekonomikos ir nekilnojamojo turto vadybos katedroje. Be bendru intelektinèms mokymo sistemoms komponentų - studento modelio, pedagoginio modelio, disciplinų duomenų bazès ir grafinès sąsajos, ị naują sistemą įtrauktas sprendimų paramos posistemis, kompiuterinių mokymo sistemų duomenų bazè ir žinių vertinimo posistemis. Disciplinų duomenų bazeje pateikiamos 63 modulių, dèstomų Vilniaus Gedimino technikos universitete, žinios spausdinta, vaizdo bei garso forma. Studento modelis sudaro galimybę pritaikyti mokymą prie studijuojančiojo poreikių ir žinių lygio. Sprendimų paramos posistemis taikomas visuose intelektinès mokymo sistemos komponentuose, suteikia jiems skirtingo lygmens intelektualumo savybių. Kompiuterinių mokymo sistemų duomenų bazė leidžia naudotis šiomis internetinėmis mokymo sistemomis: statybos, nekilnojamojo turto, pastatų ūkio valdymo, tarptautinès prekybos, etikos, inovacijų, subalansuotos plètros, renovacijos ir kt. Pedagoginis ir žiniu vertinimo modelis pateikia kitą - mokymo proceso modelį, padeda pereiti ị kitą žinių lygmenį. Grafinė sąsaja sukuria efektyvų dialogą tarp sistemos ir vartotojo. 